\title{
ON THE INFRAGENERIC CLASSIFICATION OF PINGUICULA
}

\section{AndReas FleischmanN • Botanische Staatssammlung München • Menzinger Strasse 67 D-80638} Munich • Germany•fleischmann@bio.lmu.de

Keywords: taxonomy, butterworts, systematics, Pinguicula, classification.

Abstract: In this article, the morphology-based "traditional" infrageneric classification of the genus Pinguicula is opposed to "modern", phylogeny-based concepts. But concepts are compared and illustrated, and a new infrageneric concept of four sections for the Central American evolutionary linage of Pinguicula is proposed.

The genus Pinguicula comprises about 115 species currently recognized ${ }^{1}$ (and several more named).

Three subgenera have been defined within the genus by Barnhart (1916), and many sections have been added to these later. This has been the outcome of morphological analyses, largely founded in the 1960s (Ernst 1961; Casper 1962, 1963, 1966). The three major subgeneric lineages were also confirmed by all recent molecular reconstructions of the genus' evolutionary history (Cieslak et al. 2005; Degtjareva et al. 2006; Beck et al. 2008; Fleischmann \& Roccia 2018; Shimai et al. 2021). However, the circumscriptions of these three subgenera, that is which sections and species should belong into which subgenus, differ greatly between the morphologically defined approach and the molecular phylogenetic concepts. This led to two different "schools" and the usage of two largely incompatible classifications in recent publications dealing with the systematics and taxonomy of Pinguicula, one applying the morphological concept founded by Casper's work (Casper 1963, 1966), the other one following the phylogenetic approach. For the latter, a new infrageneric classification of Pinguicula in accordance with phylogenetic data has been proposed by Fleischmann \& Roccia (2018). In the present article, both classifications for the genus are compared (see Figs. $1 \& 2$ ).

Pinguicula classifications - flowers or genes, what tells us the truth?

The "classic", morphology-based classification of the genus Pinguicula (see Fig. 1) largely considers flower characters to arrange the species in subgenera, sections, and even several ranks below (subsections and series). Casper $(1962,1963,1966,2019)$ considered of great taxonomic value the shape of the corolla (two-lipped=bilabiate or zygomorphic versus radiate=isolobate or actinomorphic), the length and shape of the corolla tube (funnel-shaped versus short and sack-like) and the spur (straight vs. curved, narrow and thin vs. short and sack-like, the angle the spur forms with the corolla tube, etc.), the presence and shape of a corolla throat (=palate), the pattern of hairs on the corolla interior (mainly: three rows of hair vs. different pattern), but also corolla color patterns. Casper also considered other characters for his classification, but

\footnotetext{
${ }^{1}$ The species concept used here is following Fleischmann \& Roccia (2018). The species described past 2018 have been included here, with the exception of the Mexican P. michoacana, which is considered by the author part of the widespread $P$. oblongiloba, and the Cuban P. baezensis which is considered conspecific with P. bissei, and P. moaensis, which seems to be conspecific with P. lippoldii.
} 


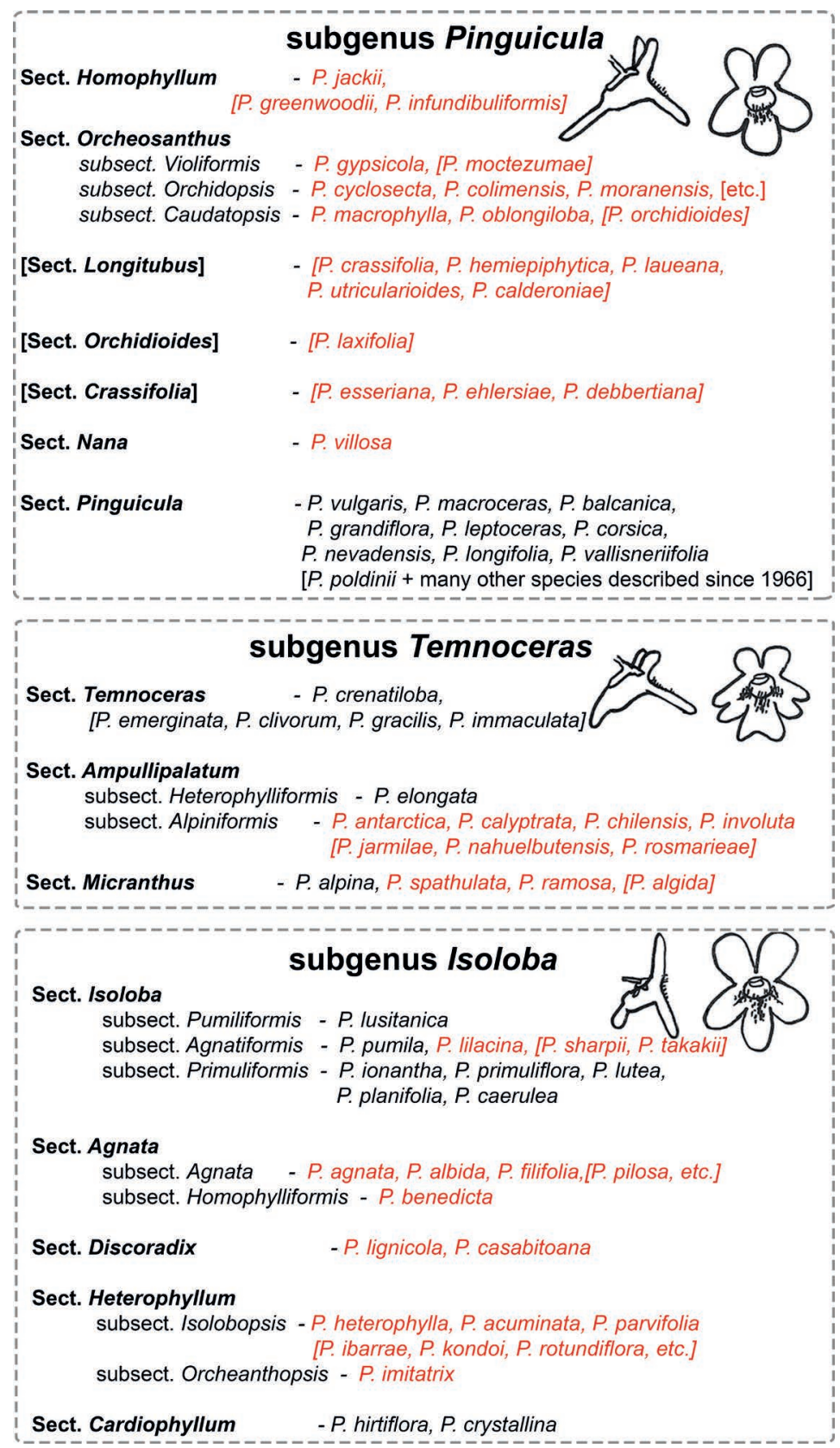

Figure 1: "Traditional", morphology-based classification of the genus Pinguicula, following Casper (1962, 1963, 1966) and Casper \& Stimper (2009). In that system, the subgenus division is mainly based on the coloration and shape of the corolla (thumbnail images). Sections and species that were added after Casper's monograph (Casper 1966) by various authors are in square parentheses, but not all new species are added here. In red are conflicting species that do not fall in the respective subgenera in any of the phylogenetic reconstructions (see Fig. 2). 


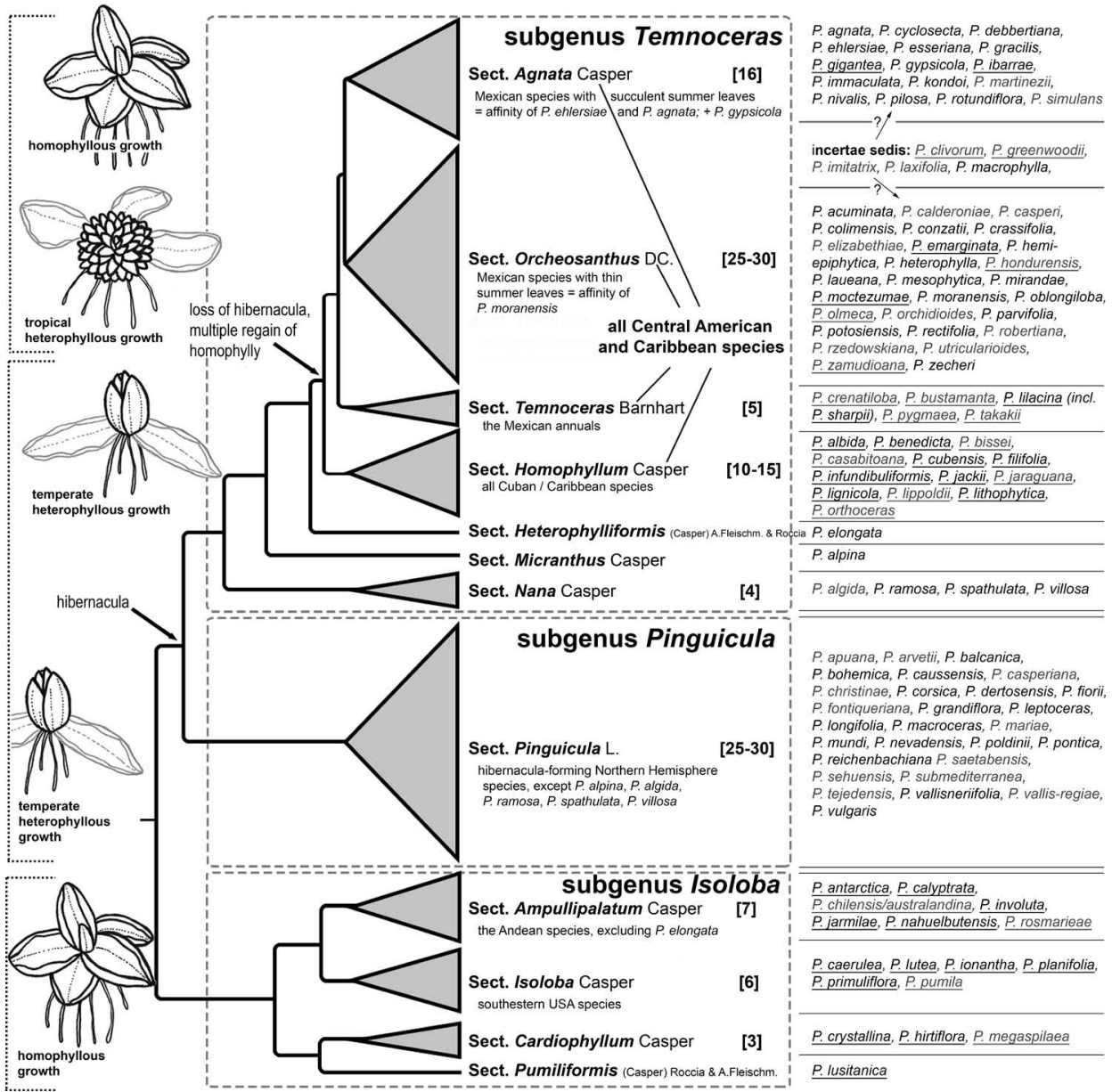

Figure 2: Phylogeny-based classification of Pinguicula, adopted from Fleischmann \& Roccia (2018). The clade of Central American species, considered a single section Temnoceras by them is here split further into four sections, reflecting the phylogenetic results by Shimai (2017) and Shimai et al. (2021). This classification mirrors the evolutionary history of the genus, with every monophyletic terminal lineage treated as a section. The widths of the triangles correspond to species numbers given in square brackets. Species that have not yet been included in phylogenetic reconstructions in grey, these are assigned to the respective sections based on postulated affinities or morphological similarities. Underlined species names $=$ homophyllous growth. 
he rated the floral characters by far the highest value: "The character complex of the flower is complemented by the taxonomically 'valuable' characters of growth form, chromosome number, life form and distribution." (Casper 1966, p. 59, literally translated from the German original). Casper further explains that "the character complex flower can serve as 'standard' for the evaluation of the genealogical connections, as it did not undergo any or just indiscernible functional changes [during evolution]. All remaining characters can be measured with it." (Casper 1966, p. 59). However, Casper's assumption of "floral functional stability" has proven fundamentally wrong in the light of evolutionary concepts, as certain flower characters can be switched quickly during evolution in adaptation to new pollinator groups or when new floral syndromes evolve, especially in young evolutionary lineages that are still in the process of biological radiation - this holds true for any group of plants, including Pinguicula (Cieslak et al. 2005; Fleischmann 2016; Fleischmann \& Roccia 2018; Lustofin et al. 2020; Shimai et al. 2021). This can result in closely related species displaying quite different, diverging floral morphology (= divergent evolution), but also in rather distantly related species that show strikingly similar flower shapes (= convergent or parallel evolution) - both can be visualized in Figure 3. An example of the former case is that of the two closely related Mexican species Pinguicula gracilis and $P$. rotundiflora (both have rosettes that are very similar, both share a similar habitat and distribution range, and both can easily be hybridized in cultivation; pers. obs.). However, both apparently adapted to quite different pollinators, as the former species shows a distinctly two-lobed corolla, with a large corolla lower lip and a comparatively small upper lip. Pinguicula rotundiflora, as already its name implies, has an isolobate corolla, i.e., a radiate flower in which all five petals are almost the same length. This led Casper and others (Studnička 1985; Zamudio 1988; Casper \& Stimper 2009) to the conclusion that the two species should belong to two different subgenera, based on the divergent flower shapes, i.e., they were considered not to be closely related: P. gracilis was either placed in $P$. subgenus Temnoceras section Temnoceras (Zamudio 1988) or in the newly created P. section Microphyllum of subgenus Temnoceras (Luhrs \& Lampard 2006; Casper \& Stimper 2009) based on its twolipped corolla, while $P$. rotundiflora was put in $P$. subgenus Isoloba section Isolobopsis because of its radiate corolla (Fig. 1). However, all molecular phylogenetic studies that included these two taxa independently show that both are closely related sister species (Shimai \& Kondo 2007; Lustofin et al. 2020; Shimai et al. 2021), which exposes their different subgeneric/sectional classification based on flower morphology as artificial, so it does not mirror their natural affinity. There are several more examples where morphology-based concepts and phylogenetic results are in conflict. Hence, we need to have a closer look at both concepts here in order to understand why there is some discordance regarding the placement of some species in the respective sections and subgenera.

Casper $(1963,1966)$ circumscribed the three subgenera as follows:

P. subgenus Isoloba Barnhart comprised species with radiate (isolobate), 5-merous corolla (but Casper also included here a few species with bilabiate corolla, such as the Cuban P. benedicta), with the petals more or less equal in size, the hairs of the corolla tube arranged in three rows, and flowers containing some yellow-colored parts. This section, according to Casper (1966) only comprised species of tropical growth type, i.e., such that only form a single type of carnivorous leaves but do not form winter rosettes.

P. subgenus Temnoceras Barnhart included species with two-lipped corolla with a well-expressed corolla lower lip that has its middle lobe larger than the lateral ones, and with the lobes of the corolla lower lip distinctly notched (crenate), with unequal petals (those of the upper corolla 


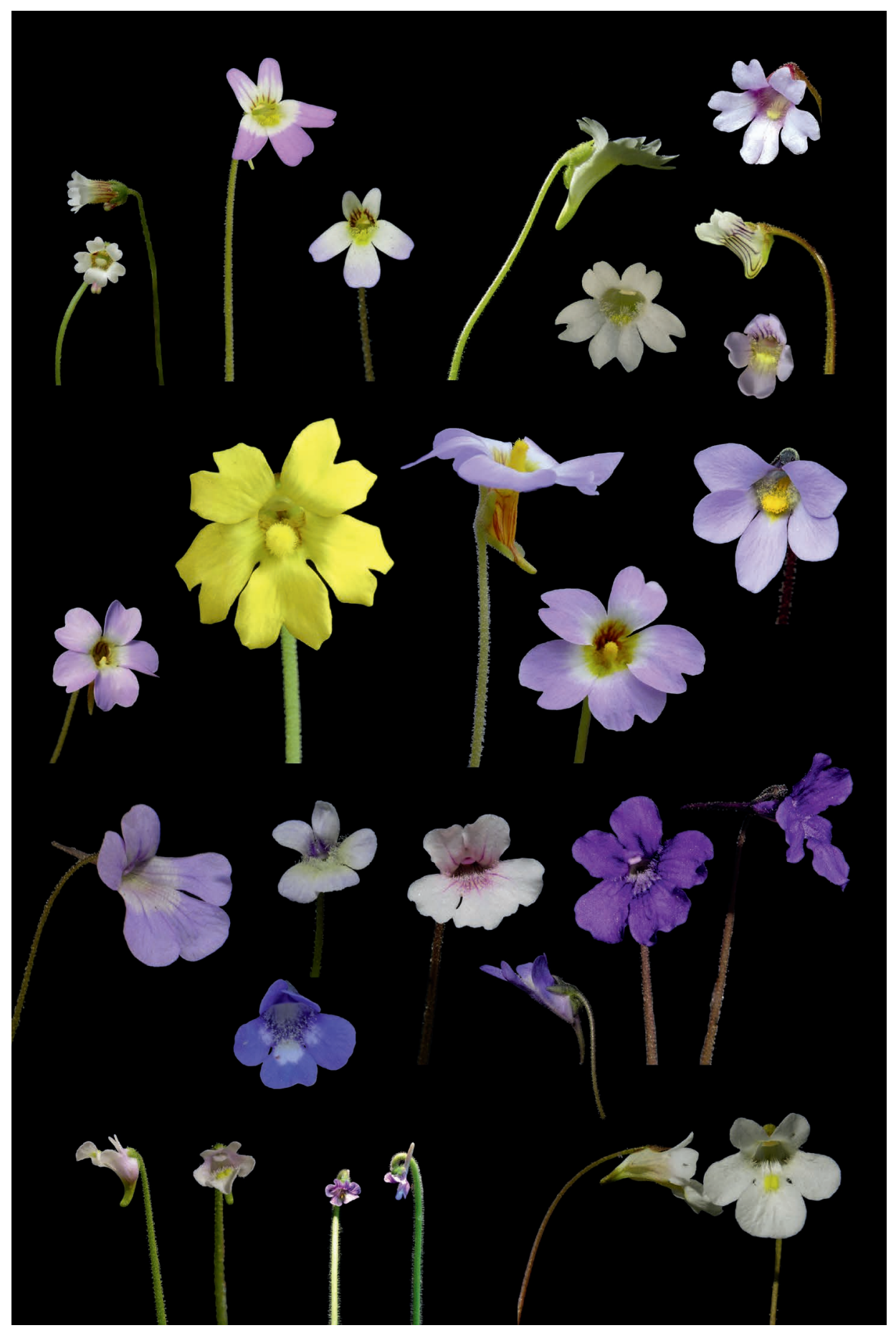




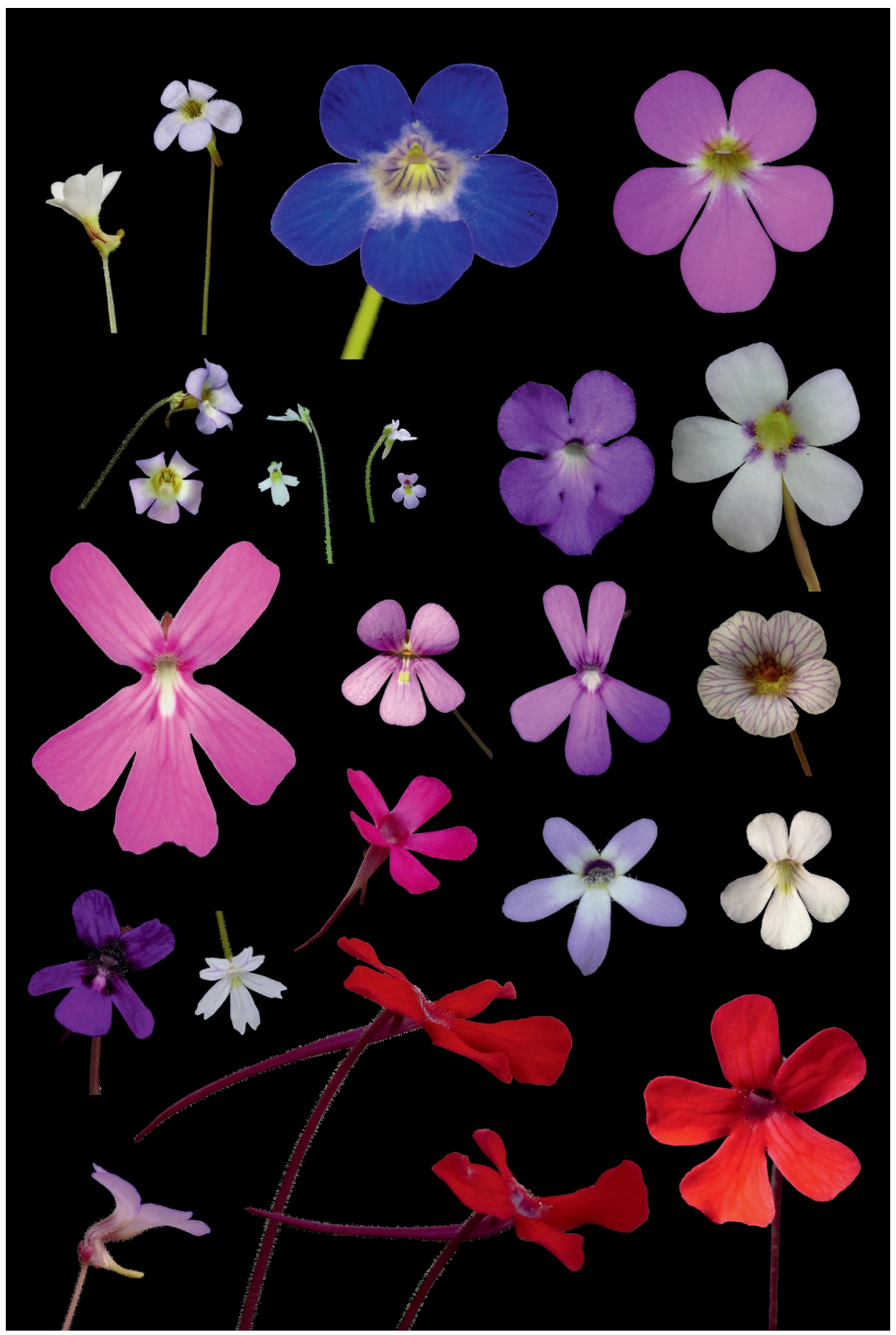




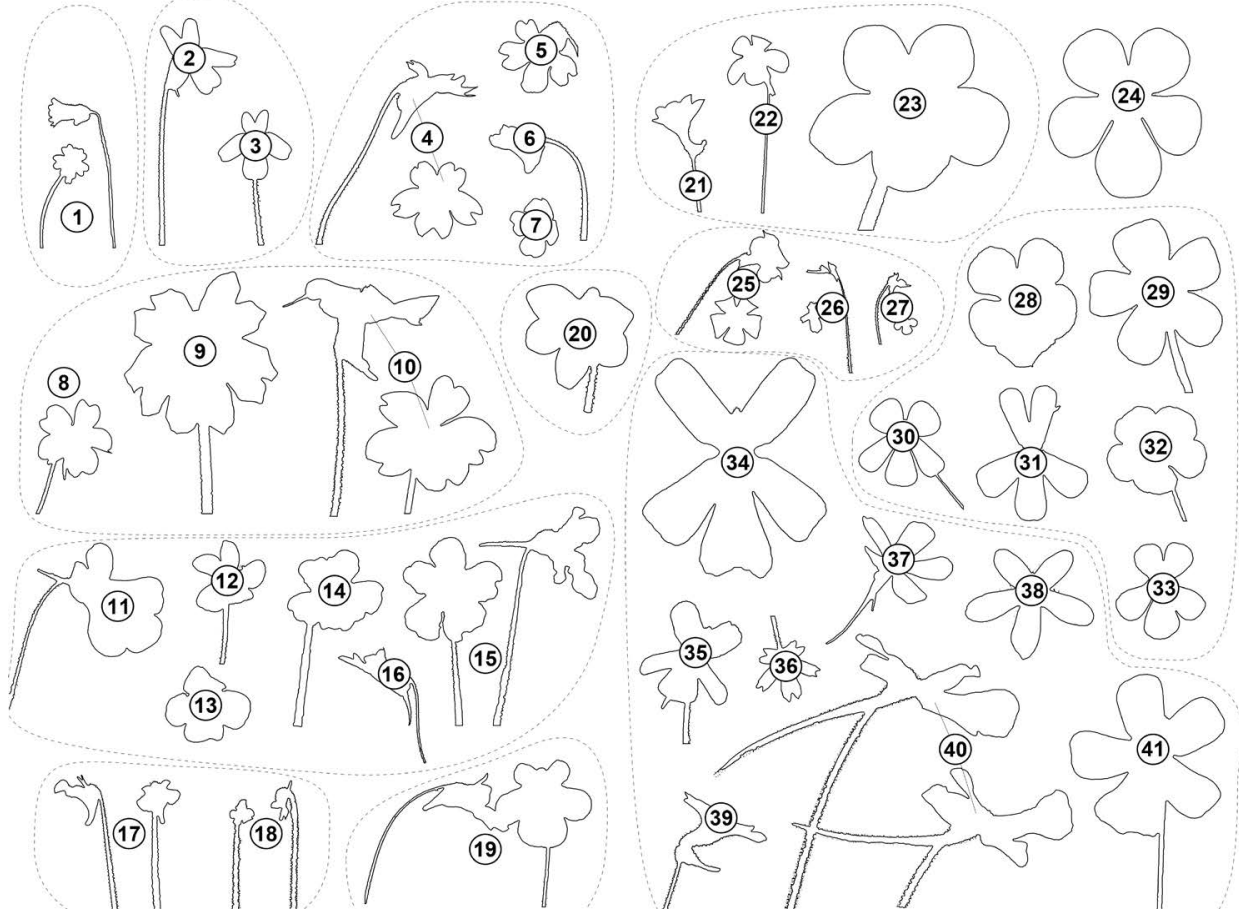

Figure 3: (preceding facing pages). Flower diversity in the genus Pinguicula. All flowers approximately to the same scale. Species arranged by phylogenetic affinity. $P$. section Pumiliformis: 1. P. Iusitanica. Section Cardiophyllum: 2. P. hirtiflora, 3. P. crystallina. Section Ampullipalatum: 4. P. jarmilae, 5. P. calyptrata, 6. P. antarctica, 7. P. nahuelbutensis. Section Isoloba: 8. P. pumila, 9. P. lutea, 10. P. primuliflora. Section Pinguicula: 11. P. longifolia, 12. P. corsica, 13. P. leptoceras, 14. $P$. grandiflora subsp. rosea, 15. $P$. grandiflora subsp. grandiflora, 16. P. vulgaris. Section Nana: 17. P. spathulata, 18. P. villosa. Section Micranthus: 19. P. alpina. Section Heterophylliformis: 20. P. elongata. Section Homophyllum: 21. P. cubensis, 22. P. filifolia, 23. P. jackii. Not assigned to any section yet: 24. $P$. laxifolia. Section Temnoceras: 25. P. lilacina, 26. $P$. crenatiloba, 27. $P$. pygmaea. Section Agnata: 28. P. cyclosecta, 29. P. agnata, 30. P. debbertiana, 31. P. gypsicola, 32. P. kondoi, 33. P. esseriana 'white flower'. Section Orcheosanthus: 34. $P$. moranensis, 35. P. moranensis 'rosei', 36. P. emarginata, 37. P. crassifolia, 38. P. parvifolia, 39. $P$. mirandae, 40. $P$. laueana 'Geranium flower', 41. $P$. laueana 'Sierra Mixe'. Photos of $P$. calyptrata and $P$. pygmaea by Fernando Rivadavia, of $P$. elongata by Sebastian Vieira, of P. antarctica, P. crenatiloba, P. lilacina, P. lutea, P. pumila, and P. villosa by Markus Welge, all other photos and image composition by A. Fleischmann.

lip much shorter), the tube hairs in three rows, and the corolla usually containing yellow colors. This section comprises species of tropical and temperate growth type (i.e., forming winter rosettes or hibernacula).

P. subgenus Pinguicula $\mathbf{L}$. covered species with a two-lipped corolla in which the lobes are always entire, and in which the corolla does not contain any yellow colors (according to Casper 1966, the only exception in that subgenus is $P$. villosa), with the tube hairs not arranged in three rows, encompassing species of tropical and temperate growth type. 
However, with the discovery of new species, but also as we gained more information about the natural variation of some Pinguicula species, it got more and more difficult to maintain Casper's above-mentioned generic classification, as certain species did not fit well any of the morphologically defined subgenera, while others showed so much infraspecific variation that they would easily fall into at least two of the subgenera. The sections put up by Casper (1962, 1963, 1966) to encompass the known Pinguicula species were likewise not sufficient anymore with the discovery of new, quite distinctive species. Some authors were uncertain where to place their new discoveries in Casper's system and left that question unanswered, or created new sections in order to fit their species. For example, Luhrs (1995) coined P. section Orchidioides exclusively for his new P. laxifolia, suggesting that this species was quite isolated and not closely related with any of the other known species. As we know today, this species belongs to a single evolutionary lineage that includes all Mexican and Central American species (= P. section Temnoceras sensu Fleischmann \& Roccia 2018). This is confirmed by the fact that $P$. laxifolia forms natural hybrids with a small-flowered form of $P$. esseriana that is sympatrically growing at the El Cielo mountains (Salinas-Rodriguez et al. 2019), thus it cannot be evolutionarily isolated. Zamudio \& Rzedowski (1991) added a new P. section Longitubus for those Pinguicula species with very long corolla tubes and long spurs (such as P. crassifolia, P. hemiepiphytica, and P. laueana; see Fig. 3). Certainly, these long-spurred, funnel-tubed flowers (which additionally show bright red, purple, or magenta colors) evolved in these species in adaptation to hummingbird pollination (Lampard et al. 2016; Lustofin et al. 2020). And obviously P. laueana and P. hemiepiphytica are much more closely related to P. moranensis (which, based on the morphological concept, was placed in a different section, $P$. section Orchidopsis), than they are to the other species (P. crassifolia, P. utricularioides, $P$. calderoniae) they have been associated with in section Longitubus. The morphological classification also shows other inconsistencies. For example, Speta \& Fuchs (1982) put up a new section Crassifolia within $P$. subgenus Pinguicula in which they placed three of the Mexican species with very succulent leaves ( $P$. debbertiana, $P$. ehlersiae, $P$. esseriana), while the likewise succulent $P$. gracilis, $P$. nivalis, and $P$. immaculata were retained by their respective authors in $P$. subgenus Pinguicula section Temnoceras, or in a newly coined $P$. section Microphyllum of subgenus Temnoceras (Luhrs \& Lampard 2006; Casper \& Stimper 2009), whereas the vegetatively almost identical, succulent species $P$. kondoi and $P$. rotundiflora were maintained even in a different subgenus - in P. subgenus Isoloba section Isolobopsis - just because of their different corolla shapes. Needless to say that all above-mentioned succulent Mexican species can be artificially hybridized (pers. obs.; many of these hybrids are found in CP growers' collections today), showing no cross-fertility borders and hence suggesting close relationship. Indeed, molecular phylogenies (Shimai 2017; Shimai et al. 2021) revealed P. esseriana, P. ehlersiae, P. gracilis, P. immaculata, $P$. nivalis, $P$. rotundiflora, and $P$. kondoi (the latter under the name $P$. reticulata) as closely related species: they all fall in the same clade, i.e., they comprise a single evolutionary lineage that evolved from a common ancestor.

Casper's weight on flower colors also had to be questioned with the discovery of new species, or variation within species. According to Casper (1966), members of $P$. subgenus Pinguicula (except P. villosa) lack any yellow color on the corolla - however, several local forms of Mexican species that were placed in that subgenus do present some yellow on the corolla tube or palate, e.g., some forms of P. moranensis, P. laueana, or P. esseriana (see Fig. 3). On the other hand, Casper (1963, 1966) defined $P$. subgenus Temnoceras for species that usually include some yellow color on their flowers. However, with the addition of $P$. jarmilae (syn. P. chuquisacensis) to the very natural group 
of the Andean species ( $=P$. section Ampullipalatum, which is a monophyletic lineage, if $P$. elongata is excluded, as the latter belongs the lineage of the Central American species; Beck et al. 2008) that concept did not fit anymore, as $P$. jarmilae does not show any trace of yellow on its corolla. In that case, Casper (pers. com. 2017) admitted that this species should belong to P. section Ampullipalatum, but that his color concept had to be re-evaluated.

To sum it up: the infrageneric concept which largely was based on flower morphology does in several cases not mirror the natural affinities but divides related species into different sections or even subgenera, whereas in other cases, only distantly related species are artificially grouped together.

All three subgenera as defined by Casper (1966), and all but one of his morphologically circumscribed sections were retrieved as para- and polyphyletic in all of the molecular phylogenies. 'Paraphyletic' means that a defined group also comprises species that were previously classified as belonging to other groups: for example, Casper's P. section Isoloba (which is by definition the evolutionary lineage (=clade) that comprises the section's type species - for Isoloba this is $P$. pumila) included species from various lineages (corresponding to $P$. subgenus Isoloba and $P$. subgenus Temnoceras sensu Fleischmann \& Roccia 2018) in phylogenetic reconstructions (Cieslak et al. 2005; Degtjareva et al. 2006; Shimai et al. 2021). 'Polyphyletic' means that members of a defined group that was thought to be a natural evolutionary lineage show up in different places (clades) in the phylogenetic tree. For example, what Casper (1963, 1966) circumscribed as $P$. subgenus Pinguicula phylogenetically divided into two subgenera: $P$. subgen. Pinguicula and $P$. subgen. Temnoceras and into four sections ( $P$. sections Pinguicula, Orcheosanthus, Agnata, and Homophyllum, as reclassified here). The contrary would be 'holophyletic', i.e., that after phylogenetic analysis, an identified lineage still contains all members originally assigned to one named group and excludes all members originally placed in different groups (of comparable rank), and 'monophyletic', i.e., that all members of a named group indeed belong to a common evolutionary lineage (clade), i.e., they were all derived from a single common ancestor. In the case of the butterworts, only P. section Pinguicula (that is the temperate, hibernacula forming species excluding P. alpina, P. ramosa, P. spathulata, P. algida, and $P$. villosa) as defined by Casper $(1962,1963,1966)$ was found to be monophyletic in all phylogenetic reconstructions.

However, it is important to mention that molecular phylogenies also cannot be considered the 'single, final truth'. These family trees should rather be considered hypotheses that try to reconstruct the evolutionary history of a group of plants as best as possible. The quality of a phylogeny depends on many factors, most importantly a complete taxon sampling (the more of the known species are included, the closer the phylogenetic tree will come to the evolutionary history of a genus; of course, nobody is able to tell about the lineages and species that got extinct during the millions of years of evolution without leaving fossil remnants, and it is almost impossible to predict what taxa will be discovered and described in future). Depending on the genetic markers used, the respective phylogenetic reconstructions may show incongruences between nuclear (inherited by both parents) and plastid (inherited only by a single parent, in most plants by the mother lineage) marker data.

The molecular phylogeny-based classification is in accordance with growth form (Fig. 2), and also largely mirrors geography (Cieslak et al. 2005; Beck et al. 2008; Fleischmann \& Roccia 2018; Shimai et al. 2021). Based on phylogenetic results, Fleischmann \& Roccia (2018) proposed a new infrageneric classification of Pinguicula, in which the three major clades correspond to the three subgenera, and all subclades were defined as sections (Fig. 2). 
Further subdivision of $P$. section Temnoceras, the Mexican and Caribbean butterworts

All Central American and Caribbean Pinguicula species were retrieved as a monophyletic lineage in all phylogenetic reconstructions (Degtjareva et al. 2006; Shimai et al. 2007; Kondo \& Shimai 2007). Therefore, Fleischmann \& Roccia (2018) united them in a single, large $P$. section Temnoceras that comprises ca. 60 species. However, Shimai et al. (2021) in their large-scale phylogeny retrieved four well-supported subclades within that lineage: one comprising all Caribbean species, one covering the Mexican annuals (represented by P. lilacina and P. sharpii in their phylogeny, two taxa which however are considered conspecific by Lampard et al. 2016, Roccia et al. 2016, and Rivadavia et al. 2017, and which are even given as synonyms in Appendix S1 of Shimai et al. 2021). Another lineage covers the species with very succulent carnivorous leaves with margins involute only near the very tip or not involute at all, i.e., the relatives of $P$. agnata and of $P$. esseriana, and additionally $P$. gypsicola was found in that group by Shimai et al. (2021). However, also P. macrophylla was retrieved among those species in the analyses of Shimai et al. (2021), which one would rather assume in the fourth clade, comprising all the species with larger, thinner carnivorous leaves with leaf margins involute along their lateral margins, i.e., P. moranensis and allies, but also P. moctezumae and P. heterophylla with upright, thread-like leaves and revolute margins (a habit similar to that of $P$. gypsicola). Following the infrageneric classification of Fleischmann \& Roccia (2018), these four subclades of Shimai et al. (2021) might be considered subsections within a monophyletic $P$. section Temnoceras. However, that would have necessitated several new combinations and the rejection of well-established names for some of the Mexican lineages. Hence these four subclades are here considered four sections (see Fig. 2) for what Fleischmann \& Roccia (2018) treated as a single one (P. section Temnoceras).

Some of the clades have already been given names at the rank of section by Shimai (2017), however unfortunately, these names are not validly published as they were published in a $\mathrm{PhD}$ thesis, which does not constitute a nomenclaturally effective publication according to the Code of Nomenclature (ICN Art. 30.9; Turland et al. 2018). Even if the newly proposed section names of Shimai (2017) had been published effectively, in order to be validly published all clades recognized by them would have required the usage of the oldest available name at the rank of section, if a member in any clade was the type of any previously defined section. Additionally, those new combinations made by Shimai (2017) that were based on Casper's (1966) earlier subsectional and series names are not validly published because no basionym reference was given (ICN Art. 41.5). Therefore, new section circumscriptions are proposed here for those lineages (clades) that thus far have not been correctly assigned to any named group in the genus Pinguicula.

P. subgenus Temnoceras section Homophyllum Casper (1963: 325)

Type species: P. jackii Barnhart

$=P$. section Discoradix Casper

$=P$. subsection Homophylliformis Casper

$=P$. subsection Agnata Casper, p.p. (P. albida, P. filifolia)

$=P$. section Caribensis Shimai, nomen

The oldest available names for a group comprising the Caribbean species, i.e., corresponding to the Cuban lineage or 'Clade IX' of Shimai et al. (2021) are P. subsection Homophylliformis (put up by Casper (1966) for P. benedicta) and P. section Homophyllum (sensu Casper 
1963, 1966 encompassing only P. jackii; other species from Mexico have been added by different authors later, see Fig. 1). Casper (1966) placed the remainder of the Cuban species with radiate corolla into $P$. section Agnata subsection Agnata (together with the Mexican species P. agnata). Later, Casper \& Stimper (2009) suggested to transfer P. albida into P. section Isolo$b a$. The name $P$. section Homophyllum is chosen here for the Cuban evolutionary lineage, as it is the oldest available one for that lineage at the rank of section. It is transferred from $P$. subgenus Pinguicula, where it was placed by Casper, to $P$. subgenus Temnoceras, in accordance with the phylogenetic topology (Shimai et al. 2007; Shimai 2017; Shimai et al. 2021). In later works, Casper himself considered the placement of $P$. jackii in his section Homophyllum separated from the other Cuban taxa, an unsatisfactory makeshift (Casper \& Stimper 2009) or even "incorrect" (Casper 2019: 116) and explained it to have been based on poor knowledge on the actual relationships of $P$. jackii, a species he previously considered to be quite isolated within the genus. With the new circumscription of Casper's section Homophyllum as P. subgenus Temnoceras section Homophyllum, that lineage will not only encompass $P$. jackii, but it contains all Caribbean Pinguicula species, in accordance with phylogenetic data that show the monophyly of the Cuban taxa (Shimai et al. 2007; Shimai et al. 2021; unpublished ITS data cited in Casper 2019: 117). Casper's section Discoradix, which he put up for the two epiphytic species with modified anchoring roots (P. lignicola and P. casabitoana) fully falls into that lineage as well, as evidenced by phylogenetic analyses (Shimai et al. 2007; Shimai et al. 2021).

\section{P. subgenus Temnoceras Barnhart (1916: 46) section Temnoceras}

Type species: P. crenatiloba DC.

$=P$. subsection Agnatiformis Casper, p.p. (P. lilacina)

$=P$. section Membraniformis Shimai, nomen

This section, as redefined here (different from the usage by Fleischmann \& Roccia 2018), includes the Mexican annuals, which are delicate species with thin, membranous leaves. The autonymous type section of subgenus Temnoceras by definition is the lineage that includes the type species of that subgenus, i.e., P. crenatiloba. Although that species had not been included in any phylogenetic analyses yet, it is evidently closely related to the other delicate Mexican annuals, P. lilacina, P. takakii, and P. pygmaea (Rivadavia et al. 2017). Clade VI of Shimai et al. (2021) covers these annual species, represented in their sampling by $P$. lilacina and $P$. sharpii, or respectively, by two accessions of $P$. lilacina if you consider both species conspecific (Lampard et al. 2016; Rivadavia et al. 2017). Based on morphological similarities (Rivadavia et al. 2017), P. crenatiloba is likely to fall into that clade as well.

The phylogenetic position of the newly discovered P. bustamanta (Zamudio \& Nevárez-de los Reyes 2020) has not been revealed yet, however it is here tentatively placed in $P$. subgenus Temnoceras section Temnoceras (in accordance with Zamudio \& Nevárez-de los Reyes 2020, who placed it in P. section Isoloba subsection Agnatiformis (sensu Casper 1966), suggesting a close affinity to $P$. lilacina). Indeed, $P$. bustamanta, although a perennial, fits well morphologically the remainder of the annual species of $P$. section Temnoceras. Interestingly, the perennial homophyllous habit of $P$. bustamanta with its thin membranous leaves seems to link it to the Cuban species of $P$. section Homophyllum, to which P. section Temnoceras is the consecutive sister lineage in the phylogenetic tree (Fig. 2; Shimai et al. 2021). The overall habit, as well as flower morphology of P. bustamanta are indeed strongly reminiscent of some of the Cuban species, most notably P. jackii and P. lithophytica - and coincidentally, these 
three limestone-dwelling lithophytic species are unique within the genus in having leaves with a row of long-stalked glandular hairs present on the midrib on the lower (abaxial) leaf surface. It would be highly desirable to include $P$. bustamanta in molecular phylogenetic analyses of the genus. In case it will turn out as early-branching taxon within P. section Temnoceras, this would confirm the postulated theory of a surviving 'missing link' between the Caribbean and Mexican lineages of Pinguicula (see e.g., Casper 2019), i.e., between sections Homophyllum and Temnoceras.

P. subgenus Temnoceras section Orcheosanthus DC. (1844: 27)

Type species: P. moranensis Kunth

$=P$. section Heterophyllum Casper

$=P$. section Longitubus Zamudio \& Rzed.

$=P$. subsection Orchidopsis Casper, p.p. (P. moranensis, P. colimensis)

$=P$. subsection Caudatopsis Casper p.p. $(P$. oblongiloba $)$

$=P$. subsection Infundibulares Zamudio \& Rzed.

$=P$. subsection Utriculariopsis Zamudio \& Rzed.

$=P$. section Mesoamericana Shimai, nomen, nom. superfl.

DeCandolle (1844) put up the oldest available name at the rank of section for the clade comprising P. moranensis, which corresponds to Clade VII of Shimai et al. (2021). This is also the taxonomic name most frequently used in the literature for the group of large, 'orchid-flowered' Mexican butterworts (e.g., Zamudio 2001; Casper \& Stimper 2009) which belong to that evolutionary lineage.

P. subgenus Temnoceras section Agnata Casper (1963: 331), emend. A.Fleischm.

Type species: $P$. agnata Casper

$=P$. section Crassifolia Speta \& F.Fuchs

$=P$. section Microphyllum Luhrs

$=P$. subsection Agnata Casper, p.p. (P. agnata)

$=P$. subsection Violiformis Casper

$=P$. subsection Orchidopsis Casper, p.p. $($ P. cyclosecta $)$

The newly circumscribed $P$. section Agnata excludes the Cuban species which Casper (1966) assigned to that section ( $P$. albida, P. filifolia, $P$. benedicta). These are now all included in $P$. section Homophyllum. Pinguicula section Agnata as recircumscribed here includes all Mexican species with succulent summer leaves, i.e., the relatives of P. agnata, P. esseriana (= those species previously classified in section Crassifolia), and those of $P$. gracilis (= species previously included in section Microphyllum). Additionally, it includes P. gypsicola which, although a species with membranous, filiform summer leaves, seems to be derived from ancestors with succulent summer leaves, judging from its phylogenetic position (Shimai et al. 2021). It would be interesting to reinvestigate the phylogenetic position of P. macrophylla, which turned up in the same clade as the succulent-leaved species in the analysis of Shimai et al. (2021), although it would morphologically indicate a closer relationship with $P$. section Orcheosanthus (see Casper 1966; Zamudio 2001).

The two section names chosen here for the two evolutionary lineages of perennial Mesoamerican Pinguicula species might fit Casper's later view on that group, which he referred to as "the Central American Orcheosanthus and Agnata species groups" (Casper 2019: 110). 
For biological reasons, it might have been better to choose subsections, not sections, to name the four lineages of Mexican and Caribbean species (as retrieved by Shimai et al. 2021) because the Mexican and Cuban species are interfertile (see below), while between the sections as circumscribed by Fleischmann \& Roccia (2018), there are fertility-barriers, as explained further below. Also, the Mexican species all seem to be interfertile: this is well-known for the two clades defined here as sections Orcheosanthus and Agnata, as numerous artificial hybrids (and cultivars) exist that have been created between species that fall into these two sections (e.g., $P . \times$ 'Weser' and $P . \times$ 'Sethos', which involve crosses between P. moranensis of section Orcheosanthus and P. ehlersiae of section Agnata, but there are many more examples of such Mexican inter-section hybrids made by talented butterwort breeders). The annual members of $P$. section Temnoceras with their delicate flowers are apparently also interfertile with the remainder of Mexican species (that often exhibit very different flower morphologies), as is evident from the discovery of a natural hybrid between P. takakii (section Temnoceras) and P. gypsicola (section Agnata) by F. Rivadavia (Rivadavia 2003).

Pinguicula systematics and hybridization - can I create any imaginable butterwort hybrid?

One interesting "side-effect" of the phylogeny-based classification by Fleischmann \& Roccia (2018), in which all subgenera and sections represent monophyletic evolutionary lineages, is that it apparently reflects well the cross-compatibility borders: within a given section, all species can be (artificially) hybridized with each other, no matter of geography (at least I do not know of any example that shows the contrary, but of a lot of examples which confirm this theory; by the way, the same holds true for Drosera hybridization and the phylogeny-based classification of Drosera). For example, all Mexican Pinguicula species (which all belong to a large P. section Temnoceras in the concept of Fleischmann \& Roccia 2018) can hybridize, at least in cultivation, and also the Mexican and Cuban species can be hybridized with each other (I made the hybrid between the Cuban P. jackii and Mexican P. agnata, and on the internet, there are trustworthy photographs that show the putative hybrid of $P$. moctezumae and P. filifolia).

The "stand-alone" species of the monotypic sections Micranthus (P. alpina), Heterophylliformis (P. elongata) and Pumiliformis ( $P$. lusitanica) cannot be hybridized with any other Pinguicula species (pers. obs.). And for the same reason, it will not be possible to create an artificial hybrid between a member of the P. hirtiflora complex ( $P$. section Cardiophyllum) and one of the hibernacula-forming temperate species of $P$. section Pinguicula (I have tried doing so many times without success), or any Pinguicula species from any other section.

There is a single report of what would represent the rare case of an inter-sectional (and in fact also across-subgenus) hybrid in Pinguicula: Wettstein (1919) described a pollen-sterile, pale lilac-flowered putative natural hybrid between $P$. alpina and $P$. vulgaris (both which belong to different subgenera and sections) which he named as P. $\times$ hybrida. That hybrid is repeatedly mentioned in the literature (e.g., Ernst 1961; Casper 1966). But apart from the three herbarium specimens that comprise the historic type collection from Lower Austria south of Vienna, one collection from Finland and one from Slovakia (Casper 1966), that hybrid has never been relocated, despite the fact that both putative parent species are often found growing in close proximity in the European Alps. In my opinion, the identity of that hybrid is highly doubtful, and its description was probably based on pale-flowered forms of P. vulgaris, which are more or less frequent among normally-colored individuals in many European populations of that species (pers. obs.). Interestingly, the flower of the putative hybrid as depicted by Wettstein (1919) is 
notably smaller than those of both parent species, and rather matches that of P. vulgaris in overall shape and morphology. From a phylogenetic perspective, that hybrid is unlikely to exist, and P. alpina and $P$. vulgaris are apparently cross-incompatible: despite having tried to artificially hybridize both species for more than 20 years (almost every season both species are in flower at the same time in my garden), I have never obtained even a single hybrid seed grain, but just got aborted seed capsules, no matter which way round I tried to perform that cross. Curiously, that putative hybrid was apparently once grown in cultivation from unknown source by the late German CP grower Uwe Westphal (pers. coms; I have never seen his plant personally, thus I cannot confirm or reject its identity).

Acknowledgements: The late Jost Casper, Aymeric Roccia, Fernando Rivadavia, Jan Schlauer, Julian Hernández, Sergio Zamudio, Maurizio Saroldi, Oliver Gluch, for correspondence on Pinguicula taxonomy over the past decades. Markus Welge, Kamil Pasek, Eric Partrat, Maurizio Saroldi, Klaus Keller, Stefan Ippenberger, and Paul Debbert for sharing some of their cultivated Pinguicula treasures with me. Jan Schauer and John Brittnacher are thanked for helpful comments on the manuscript.

\section{References}

Barnhart, J.H. 1916. Segregation of genera in Lentibulariaceae. Memoirs of the New York Botanical Garden 6: 39-64.

Beck, S.G., Fleischmann, A., Huaylla, H., Müller, K.F., and Borsch, T. 2008. Pinguicula chuquisacensis (Lentibulariaceae), a new species from the Bolivian Andes, and first insights on phylogenetic relationships among South American Pinguicula. Willdenowia 38: 201-212.

Candolle, A.P. de 1844. Prodromus systematis naturalis regni vegetabilis, Vol. 8. Fortin, Masson et Sociorum, Paris.

Casper, S.J. 1962. Revision der Gattung Pinguicula in Eurasien. Feddes Repertorium 66: 1-148.

Casper, S.J. 1963. Gedanken zur Gliederung der Gattung Pinguicula L. Botanische Jahrbücher für Systematik 82: 321-335.

Casper, S.J. 1966. Monographie der Gattung Pinguicula L. Bibliotheca Botanica 127/128: 1-210.

Casper, S.J. 2019. The insectivorous genus Pinguicula (Lentibulariaceae) in the Greater Antilles. Englera 35: 1-126.

Casper, S.J., and Stimper, R. 2009. Chromosome numbers in Pinguicula (Lentibulariaceae): survey, atlas, and taxonomic conclusions. Plant Systematics and Evolution 277: 21-60.

Cieslak, T., Polepalli, J.S., White, A., Müller, K., Borsch, T., Barthlott, W., Steiger, J., Marchand, A., and Legendre, L. 2005. Phylogenetic analysis of Pinguicula (Lentibulariaceae): chloroplast DNA sequences and morphology support several geographically distinct radiations. American Journal of Botany 92: 1723-1736.

Degtjareva, G., Casper, S.J., Hellwig, F.H., Schmidt, A.R., Steiger, J., and Sokoloff, D.D. 2006. Morphology and nrITS phylogeny of the genus Pinguicula L. (Lentibulariaceae), with special attention to embryo evolution. Plant Biology 8: 778-790.

Ernst, A. 1961. Revision der Gattung Pinguicula. Botanische Jahrbücher 80: 145-194.

Fleischmann, A. 2016. Pinguicula flowers with pollen imitations close at night - some observations on butterwort flower biology. Carnivorous Plant Newsletter 45: 84-92.

Fleischmann, A., and Roccia, A. 2018. Systematics and evolution of Lentibulariaceae: I. Pinguicula. In: Ellison, A.M., and Adamec, L. (eds.): Carnivorous Plants: Physiology, Ecology, and Evolution. Oxford University Press, 70-80. 
Lampard, S., Gluch, O., Robinson, A., Fleischmann, A., Temple, P., McPherson, S., Roccia, A., Partrat, E., and Legendre, L. 2016. Pinguicula of Latin America. Redfern, Dorset. 362 pp.

Luhrs, H. 1995. New additions to the genus Pinguicula (Lentibulariaceae). Phytologia 79: 114-122.

Luhrs, H., and Lampard, S. 2006. A new species of Pinguicula (Lentibulariaceae) from Nuevo León, México. Carnivorous Plant Newsletter 35: 4-9.

Lustofin, K., Świątek, P., Stolarczyk, P., Miranda, V.F.O., and Płachno, B.J. 2020. Do food trichomes occur in Pinguicula (Lentibulariaceae) flowers? Annals of Botany 126: 1039-1048.

Rivadavia, F. 2003. Postcard from Mexico N³. http://www.pinguicula.org/A_world_of_Pinguicula_2/Pages/Postcard_3.htm

Rivadavia, F., Read, E.L., and Fleischmann, A. 2017. Pinguicula pygmaea (Lentibulariaceae), a new annual gypsicolous species from Oaxaca State, Mexico. Phytotaxa 292: 279-286.

Salinas-Rodríguez, M.M., Hernández-Rendón, J., and Quirino-Olvera, R. 2019. Nella Sierra de Tamaulipas alla ricerca di misteriose pinguicole. AIPC Magazine 55: 12-29.

Shimai, H. 2017. Taxonomy and conservation ecology of the genus Pinguicula L. (Lentibulariaceae). $\mathrm{PhD}$ thesis, University of Kent.

Shimai, H., and Kondo, K. 2007. Phylogenetic analysis of Mexican and Central American Pinguicula (Lentibulariaceae) based on internal transcribed spacer (ITS) sequence. Chromosome Botany 2(2): 67-77.

Shimai, H., Masuda, Y., Panfet Valdés, C.M., and Kondo, K. 2007. Phylogenetic analysis of Cuban Pinguicula (Lentibulariaceae) based on internal transcribed spacer (ITS) region. Chromosome Botany 2(4): 151-158.

Shimai, H., Setoguchi, H., Roberts, D.L., and Sun, M. 2021. Biogeographical patterns and speciation of the genus Pinguicula (Lentibulariaceae) inferred by phylogenetic analyses. PLoS ONE 16(6): e0252581.

Speta, F., and Fuchs, F. 1982. Neue Pinguicula-Arten (Lentibulariaceae) aus Mexiko. Stapfia 10: 111-119.

Studnička, M. 1985. Pinguicula rotundiflora - a new species from Mexico. Folia Geobotanica \& Phytotaxonomica 20: 201-204.

Turland, N.J., Wiersema, J.H., Barrie, F.R., Greuter, W., Hawksworth, D.L., Herendeen, P.S., Knapp, S., Kusber, W.-H., Li, D.-Z., Marhold, K., May, T.W., McNeill, J., Monro, A.M., Prado, J., Price, M.J., and Smith, G.F. (eds.) 2018: International Code of Nomenclature for algae, fungi, and plants (Shenzhen Code) adopted by the Nineteenth International Botanical Congress Shenzhen, China, July 2017. Regnum Vegetabile 159. Glashütten: Koeltz Botanical Books. DOI https://doi. org/10.12705/Code. 2018

Wettstein, F. 1919. Floristische Mitteilungen aus den Alpen. Österreichische Botanische Zeitschrift 68: 293-296.

Zamudio, S. 1988. Dos nuevas especies de Pinguicula (Lentibulariaceae) del centro y norte de México. Acta Botanica Mexicana 3: 21-28.

Zamudio, S. 2001. Revision de la sección Orcheosanthus del género Pinguicula (Lentibulariaceae). PhD-thesis, Universidad Nacional Autónoma de México, Mexico.

Zamudio, S., and Nevárez-de los Reyes, M. 2020. Una nueva especie de Pinguicula (Lentibulariaceae) de Nuevo León, México. Phytoneuron 2020-28: 1-10.

Zamudio, S., and Rzedowski, J. 1991. Dos especies nuevas de Pinguicula (Lentibulariaceae) de estado de Oaxaca, México. Acta Botanica Mexicana 14: 23-32. 